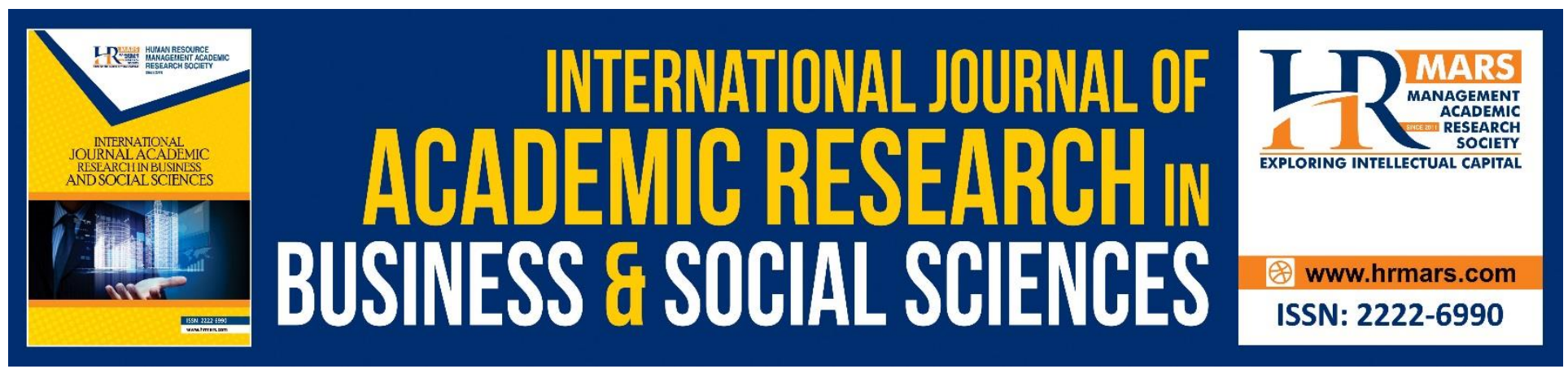

\title{
Teachers' Motivational Perceptions and Students' Academic Achievement at Oman Public Schools
}

Talal Al Rawahi, Norlizah C. Hassan, Asmah Ismail

To Link this Article: http://dx.doi.org/10.6007/IJARBSS/v8-i12/5014

DOI: $10.6007 /$ IJARBSS/v8-i12/5014

Received: 08 Oct 2018, Revised: 17 Nov 2018, Accepted: 07 Dec 2018

Published Online: 19 Dec 2018

In-Text Citation: (Rawahi, Hassan, \& Ismail, 2018)

To Cite this Article: Rawahi, T. Al, Hassan, N. C., \& Ismail, A. (2018). Teachers' Motivational Perceptions and Students' Academic Achievement at Oman Public Schools. International Journal of Academic Research in Business and Social Sciences, 8(12), 295-313.

Copyright: (c) 2018 The Author(s)

Published by Human Resource Management Academic Research Society (www.hrmars.com)

This article is published under the Creative Commons Attribution (CC BY 4.0) license. Anyone may reproduce, distribute, translate and create derivative works of this article (for both commercial and non-commercial purposes), subject to full attribution to the original publication and authors. The full terms of this license may be seen

at: http://creativecommons.org/licences/by/4.0/legalcode

Vol. 8, No. 12, 2018, Pg. 295 - 313

http://hrmars.com/index.php/pages/detail/IJARBSS

JOURNAL HOMEPAGE

Full Terms \& Conditions of access and use can be found at http://hrmars.com/index.php/pages/detail/publication-ethics 


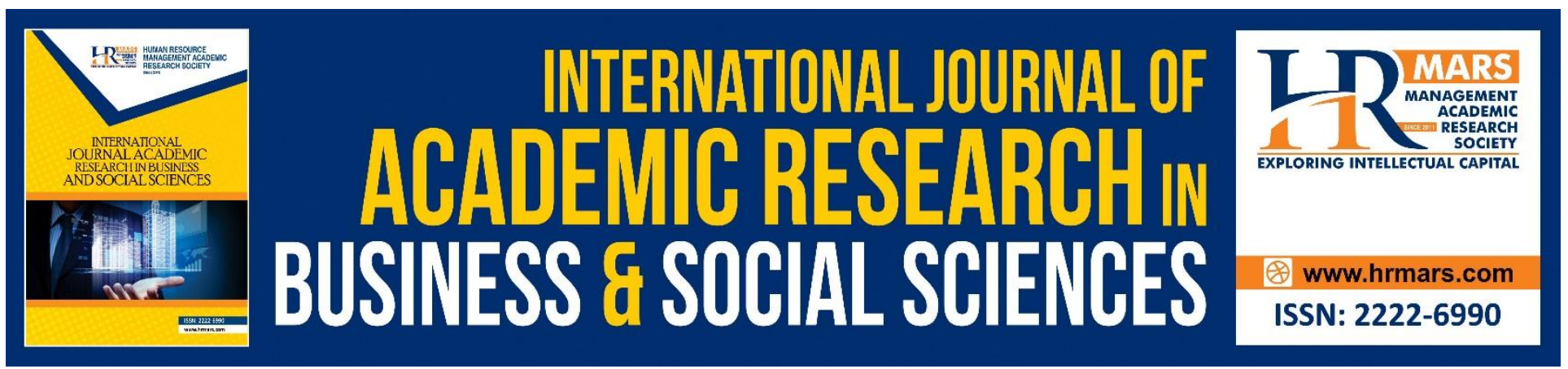

\title{
Teachers' Motivational Perceptions and Students' Academic Achievement at Oman Public Schools
}

\author{
Talal AI Rawahi, Norlizah C. Hassan, Asmah Ismail \\ Faculty of Educational Studies, University Putra Malaysia, 43400 UPM Serdang, Selangor Darul \\ Ehsan, Malaysia
}

\begin{abstract}
Motivation is an essential factor which affects students' participation and engagement in their classwork and academic achievement and grades. The main purpose of this research is to identify the level of teacher motivational perception and investigated the differences of motivational perception based on genders, grade level teach and teaching experiences. This study is a correlational survey design consisting questionnaires by Hardre' (2008), Teacher Motivational Perception (TMP) to obtain data from the respondents. A pilot study have been conducted on 30 teachers which indicates the scores of Cronbach's Alpha for TMP $(\alpha=.74)$. The study sample comprised of 135 Welayate Sumail, Al Dakhelia Governorate teachers, who taught grade 11th and 12th.. Overall, there were 64 male and 71 female teachers who taught core subjects with five years of minimum teaching experience. Results showed that there was a moderate teachers' motivational perception $(M=3.29, S D=.327$ and moderate level of students' academic achievements $(M=66.29, S D=7.11$. There are significant differences in teacher motivational perception based on gender $(t=1.137, p=.032)$ and class levels $(\mathrm{F}=3.928, \mathrm{p}=.019)$ but no significant difference $\left(x^{2}=2.008, p>0.05\right)$ in teaching experiences. The findings of this study may serve as a platform for school authorities, administrators and policymakers to develop students' motivation and motivational strategies that can be practised in Oman public schools.
\end{abstract}

Keywords: Teachers' Motivational Perceptions, Students' Academic Achievement, Gender, Grade Level And Teaching Experiences.

\section{Introduction}

Motivation is an important and critical factor in determining the success of students. In school motivation issues, secondary school students' find themselves lacking in desire to do academic task and often feel detached from their actions which caused them to lose interest and enthusiasm to accomplish their task. Students are bored in classroom because they feel they "don't belong, they feel disconnected." They lack adequate knowledge in academic background and they seem to be lagging behind; the pressure gets higher as years go by in high school (the sentiment that gives them 
INTERNATIONAL JOURNAL OF ACADEMIC RESEARCH IN BUSINESS AND SOCIAL SCIENCES Vol. 8, No. 12, Dec, 2018, E-ISSN: 2222-6990 @ 2018 HRMARS

the impression of the inability to catch up). This leads to the idea that great deal of motivation comes from good everyday teaching practices.

Earlier motivation study cases have shown that students' motivation can predict the students' outcomes like self-efficacy (Deci \& Ryan, 2002; Brook, Lee, Finch \& Brown, 2012). Many earlier studies have shown that gradual decrease in students' motivation during the passing of academic years around the world (Otis, Grouzet \& Pelletier., 2005), and a major concern amongst the education researchers (Opdenakker, Maulana \& Brok, 2012). Two types of interest (personal and situational) are important in understanding motivation (Harackiewicz \& Hidi, 2000) and students' academic achievements. Teachers' - students' motivation influence their strategies to create situational or personal interests (Linnenbrink \& Pintrich 2002). Cues that teachers gained from students' motivation create perceptions, resulting in teacher behaviours which, in turn, influence students' motivation (Hardre' \& Sullivan, 2009).

Teachers' motivational perception has also been investigated using many different methods. The individual differences of the teachers, their experiences and their perceptions can significantly affect the manner in which they teach or motivate their students' (Brophy \& Good, 1974; Skinner \& Belmont, 1993). It is seen that the students' motivation need more relevant and comprehensive studies which investigate the relationship between the teachers, students; and the challenge among the students' motivation and their academic achievements.

\section{Problem Statement}

Recently, many studies in Oman have focused on the students' motivation. Many of the students" indicator achievements obtained, but the results have not been accepted by parents. Several authorities such as the administrators in the Ministry of Education, principals, supervisors and teachers are seen to play an important role in providing the students' with aspirations and motivational strategies in achieving academic success. Based on the fact of Omani Studies, there is a lack of motivation amongst the students, results scored by the students in secondary schools, the teaching methods used by the teachers and the students' learning assessments need to develop several changes in the Omani school system (Al-Mahroqi, Shahid \& Charles, 2012). According to the Omani Educational Centre of Statistics (2016), there was difference between public students' success rates which varied within the students in grade $11^{\text {th }}$ and the $12^{\text {th }}$ for various subjects and ranged between $62 \%$ and $75 \%$ in Sumail, Oman; and students' subjects indicators showed a high-ranged recipient ratio for estimated (d=Pass) grade scores of class level (12) in subjects like Physics, Chemistry, Applied Mathematics, General Mathematics, Geography, Arabic Language, Science and Technology.In Oman, communities, educational authorities and school environments raised a concern about the students' motivation and their achievements. They made an effort to understand the issues of students' motivation which led to their academic achievements. They also studied the teachers' supervising time; academic taught courses, students' exams and the teachers' technical teachings (Al-Kharousi, Al-Dhafri, Al-Nabhani \& Al. Kalbani, 2016) required for further attention due to motivation to predict students' academic achievements. 
If the students lack of critical motivational characteristics, they are in danger of being unmotivated and achieving low in school (Schunk \& Pintrich, 2012). As an invisible, internal process, motivation can be difficult to identify and address (Hardre' 2008). If teachers can accurately identify their students' motivational needs and address them, then they can remove barriers to students' motivation and teach more effectively, and students can learn more effectively (Hidi and Harackiewicz 2000). For these reasons, it is important to investigate how teachers identified motivational needs. The previous research examining teachers and students' motivation has found teachers' prior beliefs and experiences to influence their classroom practices (Volet, 2010). Teachers' perceptions of what motivates students are not strongly related to the choice of strategy used to motivate, however the reasons for teachers' endorsement on students' lack of motivation is highly related (Hardre \& Sullivan, 2008).

In Welayat Sumai, academic achievements of grade $11^{\text {th }}$ revealed that $48 \%$ were between medium and failed, $22 \%$ were good and $22.8 \%$ were in high grades. As well as, academic achievement of grade $12^{\text {th }}$ students revealed that $51 \%$ were between medium and failed, $29 \%$ were good and $20 \%$ in high grades academic achievements. The Ministry of Education statistical reports showed that most students had low performance who scored moderate grades in grade $11^{\text {th }}$ and 12th in Al. Dakhelia, Sumail (Oman Educational Statistics, 2016). Finally, in Oman public schools, a comprehensive understanding of the gap between students' results and the different academic achievement indicators has to be studied. Hence, there were lack of research been carried out on the perceptions of the Omani teachers with regards to the students' lacking of motivation.

\section{Research Objectives}

The objectives of the study are to examine teachers' perception in how they motivate students' in their classrooms to increase students' academic motivation and performance. This study explored teachers' perceptions about students' motivation as a way to understand students' motivation towards learning among high school students. The study objectives are listed below:

1- To identify the level of motivational perception among secondary school teachers in Welayat Sumail.

2- To identify the motivational perception based on genders, grade level and teaching experience among secondary school teachers in Welayat Sumail.

3- To identify the students' academic achievements level.

\section{Literature Review}

Teacher motivational perception of students' motivation has become an important issue given their responsibility to impart knowledge and skills to learners. Specifically, the study sought to establish how teachers' motivational perception related to students' performance in secondary schools. Academic achievements is a critical issue to address in high school education, because motivational are malleable and can significantly influence the engagement, learning, achievement, future aspirations and intentions of students' (Hardré \& Reeve 2003; Hardre \& Sullivan, 2009; Schunk \& Pintrich, 2012. Many studies tried to explain the process of motivation; especially in school such as (motivational teacher-students relationship). Teachers need to support their students' motivation, 
INTERNATIONAL JOURNAL OF ACADEMIC RESEARCH IN BUSINESS AND SOCIAL SCIENCES

Vol. 8, No. 12, Dec, 2018, E-ISSN: 2222-6990 @ 2018 HRMARS

improve teacher-students' perceptions, teachers' expectations, self-efficacy, strategies and improve educational practices to develop students better. Better educational practices should be implemented in improving students' motivation (Kiefer et al., 2014).

\section{Motivation}

In any formal or informal educational setting, the most important physiological tool used for encouraging students and improve their academic performance is motivation (Schunk \& Pintrich, 2012). Hence, motivation refers to a set of factors which activate the ability of the students to work hard and achieve a defined academic objective (Black \& Deci, 2000). Motivation is an important determinant which helps in predicting the academic performance of the students and a driving force which engages their mind and helps them focus towards a specific task (Martin \& Marsh, 2006). The different components of motivation include intrinsic and extrinsic motivation, self-determination, personal relevance, self-efficacy and also, anxiety assessment (Wigfield \& Eccles, 2000). The different intrinsic forces motivate the students to engage in academic routine as they can become more passionate about learning (Black \& Deci, 2000).

Thus, the students are motivated more when their teachers expect good results and also believe in their ability to succeed (Wentzel \& Wigfield, 2009; Adkins-Coleman, 2010; Eccles \&Roeser, 2011). The teachers show their higher expectations by establishing clearer standards for striving the success, creating learning goals explicitly for their students, demanding for more efforts and also demonstrating proper levels of cooperation and assertive behaviour (Marzano \& Marzano, 1993; Anderman \& et al., 1999; Corbett et \& al., 2002; Adkins-Coleman, 2010). However, on the other hand, if the students believe the teachers' expectations as very high or as unrealistic, there could be a decline in their motivation (Daniels \& Arapostathis, 2005; Wentzel \&Wigfield, 2009, Kiefer, 2014).

Motivation towards anything is the actual human drive which acts as the basis for the search of new information and knowledge. Intrinsic motivation refers to the physical and mental involvement in the academic activities, self-reflection, self-criticism, and an acceptance of failure (Cerasoli \& et al., 2014). Extrinsic motivation is an external factor, which can be an expectation from family and friends, or basic academic requirements for enrolling into another school, university, course, etc (Wigfield \& Eccles, 2000). These extrinsic motivators are seen to distract the students from their independent ability to learn and do not work for long time durations, and this motivation declines after the motivator not present. Walker (2006) stated that the extrinsic motivating factors require a lesser effort or performance levels in comparison to the intrinsic motivating factors (Walker et al., 2006). These studied indicated that extrinsic accomplishments show a downturn effect on the intrinsic motivational spirit.

\section{Motivation Theory}

Motivation can reinforce and strengthen the beliefs and behaviors of the students who show weak or lack of motivation (Boyd \& et al., 2011). Various social-cognitive motivational theories like the achievement goal theory and the expectancy-value theory had been applied to the pre-service teachers' motivational studies. In one four-year longitudinal study, Malmberg (2008) studied the 
changes and the stability of the pre-service teachers' achievement objective orientations which studied the Finland-Swedish students's and teachers. Based on individual growth models, the researchers observed that there was a general increase in the academic performance of the students's over a period, which peaked during their third year, and this increase in their mastered goal orientation was higher than that displayed in their performance-based goal orientation (Han \& Yin, 2016).

Several theories about motivation have been stated. The Need theory is seen to revolve around fulfilling the internal state, which makes the students' display a good and successful result (Gawel, 1997). Three sub-theories of the Need theory have presented: Maslow's Pyramid Hierarchy of Need, Alderfer's ERG Model and Achievement Motivation Theory by McClelland. The Maslow's theory has stated that thee students' show a pyramid hierarchy of their needs, which need to be satisfied from the bottom to the top. Some deficiency needs are also present, which stifle all other movements if they are not satisfied, and the growth needs, which are progressively satisfied after the basic needs fulfilled. In the Alderfer's model, the five needs mentioned by Maslow condensed in three categories: Existence - it is more material and physiological, Relatedness - it is a social and an external esteem, Growth - it is a simple internal esteem and a self-actualization. According to Acquired needs theory by McClelland, the specific needs of any person can be acquired over the course of time based on their life experiences. However, he has described this to be based on achievement motivation, power motivation, and affiliation motivation. Furthermore, Adams Equity Theory has stated that the students can maintain a good balance between their input and the final result with regards to the output of the other students (Lindner, 1998). This theory has added an important point of view to the initial motivation theory wherein a comparison with their fellow counterparts, basically, with those who are in a similar module or circumstance, is seen to occur.

The Job Design Model introduced by Herzberg is the most used model in business, as it introduced the factor of 'job enrichment' for motivating the workers (Gawel, 1997). This model needs a specific practical guide on motivating the subjects. The Expectancy theory by Vroom is seen to separate the efforts from the performance and the final result. It has assumed that the behavior is an outcome of choice amongst the different alternatives which are aimed to maximize the job satisfaction and avoid loss or pain (Van Eerde \& Thierry, 1996). He further stated that increased efforts would lead to better results. Hackman and Oldham's Characteristics Model is more focused on the task itself, and it identified five major characteristics; Task identity, Skill variety, Autonomy, Task significance, and Feedback, which have influenced three of the main psychological states i.e., Meaningfulness, Responsibility and Knowledge of the results or the outcome. In this study, they observed that the situation must be gauge first before setting any goals, and he focused primarily on establishing more interpersonal differences in the motivational orientation and the setting of the goals. Being either task-involved or ego-involved expressed different aspirations in fulfilling the performance criteria. Both of these aspirations were related to the perception of the reasons for the success, the learning approaches used, school evaluation, etc. An explicit differrentiation between the increasing competence and assessing this competence led to the risearchers, i.e., Dweck and Nicholls, precisely 
INTERNATIONAL JOURNAL OF ACADEMIC RESEARCH IN BUSINESS AND SOCIAL SCIENCES Vol. 8, No. 12, Dec, 2018, E-ISSN: 2222-6990 @ 2018 HRMARS

defining the different types of the performance goals: i.e., goals which emphasized on the management and the goals which emphasized on the achievements (Radovan \& Makovec, 2015).

Furthermore, researchers have also gathered evidence which stated that extrinsic rewards would decrease the intrinsic motivation of the students', especially, if the students' anticipated such awards. However, if these rewards were not expected, the effect of such tangible rewards would be less negative on the intrinsic motivation of the students's (Deci \& et al., 2001). Currently, there are four main theories of academic motivation in the contemporary educational psychology, i.e., the achievement goal theory, attribution theory, self-worth theory and the self-efficacy theory (Seifert, 2004; Matteson et al., 2011).

\section{Teachers' Motivational Perceptions}

Their lack of motivation leads to disengagement and dropout from school and educational pursuits, a pervasive issue, more prevalent in rural than in non-rural schools (National Center for Educational Statistics, 2007).Many teachers feel ineffective in motivating, and lack the knowledge and skill to confidently, systematically diagnose and solve motivational problems, or meet motivational needs(Hardre \& Sullivan, 2008). The teachers and the education practitioners have to face the challenge of becoming more aware of such behavior and pay more attention to the interpersonal approach which results in students lack of motivation (Opdenakker \& et al., 2012). This study employed a quantitative research design examining teachers' perceptions, beliefs, and practices regarding students' motivation. 142 teachers were asked to complete questionnaires during the second half of the school year 2013. Frequency and descriptive data from the PSM and demographic data were computed and presented. Overall summary data, including the sample sizes, mean and standard deviations were computed for each item. Scales and subscales were computed in SPSS.Teacher motivational perception of students' motivation level shows a moderate level mean score $(M=3.4)$. This result could reflect declining views of elementary-/middle-school-students' motivational perception overall or a change in trend with teachers perceiving their students' as maintaining their level of motivation as they move through school ( D'Elisa, 2015).

Participants were 75 teachers in 19 public high schools in rural area in southwestern state of US. Teachers focused their responses on the questionnaires on one particular class that they were teaching during the current semester. Researchers conducted all interviews in private, collected all questionnaire materials, and maintained confidentiality of all data. Perceptions of students' motivation (PSM): This measure includes lists of 13 reasons for students' lack of motivation, which teachers are asked how strongly they endorse. Sample size, mean, standard deviation and levels were used. Teacher motivational perception of students' motivation level shows a high level mean score (M 4.4). Motivating students is a problem-solving skill, involving: identifying a problem (lack of motivation), identifying the characteristics and causes of the problem and many teachers feel ineffective in motivating, and lack the knowledge and skill (Hardre' \& Sullivan, 2008a).

Participants were 13 teachers in three rural public high schools in two US states. The teachers completed the questionnaires during their own time around the school regular schedule. Questionnaires were administered via secure online administration system, Survey- Monkey. Data 
INTERNATIONAL JOURNAL OF ACADEMIC RESEARCH IN BUSINESS AND SOCIAL SCIENCES Vol. 8, No. 12, Dec, 2018, E-ISSN: 2222-6990 @ 2018 HRMARS

was analyzed as individual case studies and then compared in parallel. Teachers' motivational perception of students' motivation level shows a high level mean score $(M=4.3)$.This finding raises questions about why schools (rural and other) are not attending to teachers' professional developmental needs with regard to motivating students (Hardre' \& Henneesy, 2010). For these reasons, it is important to investigate how teachers identified motivational needs. Furthermore, the reasons that people attribute as causes for problems, such as lack of a critical characteristic for success, often predict the strategies that they will use to solve those problems (Jonassen 2011). This is an intuitive and logical formula for generating problem solutions, in an attempt to reverse the cause of a negative condition and to correct that condition to a positive state (Hardre' et al. 2008). Holistically, teachers and students are in a dynamic motivational equilibrium. Many teachers begin with general lack of clarity and confidence in what they know about motivating students.

The teachers perception on students lacking of motivation referred to as variables which can influence the students to learn better (Sørebø \& et al., 2009). In their study, Asemah (2010) stated that the teachers' motivation was a very general term which could apply to the whole class for inducing a better academic performance. In (2011), Hicks stated that the teachers' motivation comprised all factors which positively influenced the learning process. It has been seen that in recent times, there is a decline in the teachers' motivation, as they feel that they are not receiving appropriate moral or material recognition they deserve (Bradford, 2005). Furthermore, they have also stated that there has been a massive increase in the students number per class in some of the secondary schools, where the class volume has tremendously increased, thus affecting the teaching and learning process. Small class size help the teachers impart more motivation, which could result in better academic performance. The teachers' working conditions are directly related to the learning conditions of the students lacking of motivation. The school environment which allows the teacher to carry out a good job would help in improving the learning conditions (Wang and Holcombe, 2010). There is a close relationship between the school infrastructure and the educational quality with regards to the success of the students. In several countries, the investment in the school equipment is neglected, which can hamper the teachers' motivational ability.

Many studies of motivation show a significant difference in terms of some variables such as gender, domains and grade level. In contrast, the analysis conducted by Arogul, (2011) showed no significant difference in academic motivation between male and female teachers. The findings were not supported by the findings of the researches carried out by Spittle et al. (2009) and Vallerand et al. (1992) who have found female teachers scoring higher than males. However, the results concerning gender differences were also different from Vallerand et al. (1992) and Bissonnette (1992). Unlike the findings of this study, females reported higher levels of motivation to know, to experience stimulation, identification and introjection, but lower levels of a motivation than males (Hakan and Münire, 2014).

This study will contribute to the body of knowledge on students' motivation specifically, by focusing on determining teachers' perceptions on how they motivate students in their classrooms. This may help increase students' level of participation during instruction and their overall academic 
INTERNATIONAL JOURNAL OF ACADEMIC RESEARCH IN BUSINESS AND SOCIAL SCIENCES Vol. 8, No. 12, Dec, 2018, E-ISSN: 2222-6990 @ 2018 HRMARS

performance. The earlier studies which investigated the teachers' motivational perceptions, their motivational strategies and the students' academic achievements, were seen to be based on the teachers' prior perceptions and experiences, which influenced the classroom practices (Volet, Vauras \& Salonen, 2010; Akintola, 2010). Likewise, several studies such as Motivational strategies in English Foreign Language classrooms, Motivating adolescents: Teacher perception, Academic Achievement: Causes and Results, The Factors Influencing the Motivational Strategy, Students' Motivation: Teacher Perceptions, Beliefs (Sugita and Takeuchi, 2014; Hardre' and Sullivan, 2009; Al-Zoubi \& Bani Younes, 2015; Solake and Bayar, 2014, D'Elisa, 2015) still search on relation between the factors of strategies and teachers' self-efficacy, general beliefs with relation to students' performances scores. They led the researcher to understand the correlation between the motivational strategies, self-efficacy, general beliefs with students' academic achievements indicator scores. In conclusion, the concerns among the teachers' perceptions levels; and motivational strategies used, self-efficacy, general beliefs with students' academic achievements have encouraged several studies.

\section{Methodology}

The present study is a quantitative correlated descriptive research design. The research adopted a survey method to fulfill the research purpose to find out the level and differences. This study was carried out in Welayat Sumail. Al-Dakhlia Governorate. This region is located in Central Oman and consists of eight Welaya. The researcher chose Welayat Sumail to understand the level and relationship between teachers' motivational strategy, self-efficacy, general belief with students' academic achievement indicators in their core subjects final semester 2015/2016. The reason for choosing the place of study was to take a sample of the Omani society on the issues of motivation and academic achievement. This case is considered to be the most recent research at the general level in Oman and in Welayat Sumail in particular. The Educational Supervision Office in welayat Sumail was the first to interpret indicators of students academic achievements in Oman. In addition, the nature of conflict over the issues of students' results and their relation to motivation in schools of welayat Samail is of particular importance in the post-primary stage of grades (11-12). The researcher gathered data from the teachers (for the academic year of 2016-17) teaching various subjects in the Secondary Public schools of the Al-Dakhelia Governorate, Welayat Sumail, Sultanate of Oman. Al-Dakhelia Governorate contains 140 schools, which have 5120 female and 2666 male teachers, 3025 classes, with 83341 students' (Education Statistic of Oman, 2016). However, the aim of study focused on the Welayat Sumail teachers who teach core subjects in eight schools, 132 teachers, 2538 students were presented in grade $11^{\text {th }}-12^{\text {th }}$ and used their inticators for academic achievements, with 1325 male and 1213 female students (ES, 2016). Hence, the survey respondents were all in the Welayat Sumail; wherein these studies considered the population of Sumail as the purpose sample population from 8 Welayat for the teachers who teach core subjects in grade 11$12^{\text {th. }}$. Overall, the study sample comprised of 135 teachers (64 male and 71 female) who taught core subjects with five years of minimum teaching experience. The present study applied The Perceptions of Students' Motivation (PSM) questionnaire, developed by Hardre, Davis, and Sullivan (2008). A pilot study was carried out on (30) teachers in Welayat Sumail. The consistency of the original questionnaire, Teacher Motivational Perception that estimated by the Cronbach's Alpha internally focused $(\alpha=.71)$ and externally focused $(\alpha=.70)$. The instrument was sent to the experts to validate 
INTERNATIONAL JOURNAL OF ACADEMIC RESEARCH IN BUSINESS AND SOCIAL SCIENCES

Vol. 8, No. 12, Dec, 2018, E-ISSN: 2222-6990 C 2018 HRMARS

in terms of content validity and face validity. Back to back translation was done by two Omani English teachers to translate the original instruments to Arabic language. The experts evaluated the instrument in term of consistency, language and terminology used.

\section{Findings and Discussion}

The demographics of respondent were (genders, class level and teaching experiences). Beside the technique of descriptive statistical analysis used to determine the level of teacher motivational perception and students' academic achievements (means and standard deviation) levels. The $t$-test was applied to determine the differences of motivational perception based on genders, grade level and teaching experiences. SPSS Statistics version 23.0 was used to perform all statistical analysis (descriptive statistics: means and standard deviation, $t$-test and Pearson's $r$ ) and the finding were presented in the forms of table based on measurements and the types of analysis used.

\section{Demographic Information}

This part present the demographic of the respondents such as gender, teaching experiences and grade level teach among Welayat Sumail, Oman public school respondents.

Table 1: Demographic Information of Respondents

\begin{tabular}{lll}
\hline Variables & Frequency (Teachers, N=135) & Percentage \% \\
\hline Gender: & & \\
Male & 64 & \\
Female & 71 & 47.4 \\
Teachers $\quad$ grade & Level & 52.6 \\
Teaching: & & \\
Level 11 & 65 & \\
Level 12 & 43 & 46.7 \\
Level 11\&12 & 27 & 31.1 \\
Teaching Experiences: & & 22.2 \\
1-5 years & 13 & \\
5-10 years & 38 & 9.6 \\
10-15 years & 29 & 28.1 \\
15-20 years & 44 & 21.5 \\
More than 20 years & 11 & 32.6 \\
\hline
\end{tabular}

Gender

Table 1 shows the frequency and percentage of gender in this study out of the entire 135 valid responses from the sample in nine schools at Welayat Sumail, Oman public schools. There were $47.4 \%(n=64)$ males and $52.6 \%(n=71)$ females. The number of gender in this study was unequal. The female teachers were more than male in class level (11-12). 
INTERNATIONAL JOURNAL OF ACADEMIC RESEARCH IN BUSINESS AND SOCIAL SCIENCES

Vol. 8, No. 12, Dec, 2018, E-ISSN: 2222-6990 C 2018 HRMARS

\section{Teachers' grade Level Teaching}

Table 1 shows the results of frequency analysis for teachers' grade level. Finding showed that $46.7 \%$ $(n=63)$ of teachers are teaching grade $11^{\text {th }}$ followed by teachers in grade $12^{\text {th }} 31 \%(n=42)$ and $22.2 \%$ $(n=30)$ of teachers teach both grades $\left(11^{\text {th }}-12^{\text {th }}\right)$.

\section{Teachers' Teaching Experiences}

Finding of the study shows that the highest frequency belonged to teachers who had teaching experience between 15 to 20 years (32.6\%) followed by teachers with 5 to 10 years teaching experience (28.1\%). The lowest frequencies were registered for the category of teachers who have more than 20 years teaching experience $(8.1 \%)$.

\section{Teachers' Motivational Perception Level}

The first objective of this study was to identify Teachers' Motivational Perception (TMP) level in Welayat Sumail, Oman public secondary schools. Table 2 below sumarized the finding.

Table 2: Teachers' Motivational Perception Summary Statistics

\begin{tabular}{llll}
\hline Motivational Perception & $\mathrm{N}$ & Mean & Std. Deviation \\
\hline PSM1 & 135 & 3.333 & .9384 \\
PSM2 & 135 & 3.652 & .9409 \\
PSM3 & 135 & 3.607 & .9627 \\
PSM4 & 135 & 3.437 & .9028 \\
PSM5 & 135 & 2.481 & .9914 \\
PSM6 & 135 & 2.593 & 1.0530 \\
PSM7 & 135 & 3.533 & .9207 \\
PSM8 & 135 & 2.837 & 1.0309 \\
PSM9 & 135 & 2.474 & 1.1384 \\
PSM10 & 135 & 3.141 & 1.1855 \\
PSM11 & 135 & 3.304 & 1.0739 \\
PSM12 & 135 & 4.415 & .7954 \\
PSM13 & 135 & 3.452 & 1.0053 \\
PSM14 & 135 & 2.800 & 1.1769 \\
PSM15 & 135 & 3.022 & 1.1294 \\
PSM16 & 135 & 3.356 & 1.0182 \\
PSM17 & 135 & 3.141 & 1.1340 \\
PSM18 & 135 & 4.230 & .8190 \\
PSM19 & 135 & 3.541 & 1.0979 \\
PSM20 & 135 & 3.541 & 1.0979 \\
\hline Valid N (listwise) & 135 & & \\
\hline
\end{tabular}

Table 3: Descriptive Statistics: TMP Level 
INTERNATIONAL JOURNAL OF ACADEMIC RESEARCH IN BUSINESS AND SOCIAL SCIENCES Vol. 8, No. 12, Dec, 2018, E-ISSN: 2222-6990 @ 2018 HRMARS

\begin{tabular}{llllll}
\hline & N & Minimum & Maximum & Mean & $\begin{array}{l}\text { Std. } \\
\text { Deviation }\end{array}$ \\
\hline $\begin{array}{l}\text { Teacher Motivational } \\
\text { Perception }\end{array}$ & 135 & 2.50 & 4.20 & 3.2944 & .37195 \\
\hline
\end{tabular}

Table 2 shows a descriptive analysis of teachers' motivational perceptions level which were moderate. The scores for teachers' motivational perception ranged from 2.5 to 4.20 ( $M=3.2944$, $S D=.37195)$.This study found that the majority of teacher general motivational perception of students' motivation level shows moderate mean score which can be explained by the values $(M=3.29 S D=.372)$. The finding may give an important and an inducement to the teacher to be more understanding of the reasons why the students' lack of motivation in school. The research statistical indicator of teachers' motivational perceptions is between neutral and agrees on endorsement in 5point Likert scales. In terms of Teachers Motivational Perception Instrument (cause/reasons) of students' lacking of motivation subscale "home factor, current relevance, aspiration, peer factor, personal factor" shows that peer factor subscale had the highest perception level among the reasons for students' lacking of motivation followed by personal factors and teachers who taught both grade 11 and 12 had the highest perception. Peer pressure is a vital factor that contributes to the issue of students lacking of motivation since at that age, they are vulnerable and easily influenced by their peers. The reason of students' lack of motivation is largely based upon empirical studies that investigate teachers' level of perception such as (Hardre' \& Sullivan, 2008; M=4.4); (D'Ellisa, 2015; $M=3.4$ ); (Hardre' \& Hennessey, 2013; $M=4.3$ ). The teachers' motivation perceptions endorsed that while students do need to understand that, there are consequences to their peer factors effects. When teachers have the clarification of reason why students' lacking of motivation, they create a safe, supportive environment for students affirming their belief in a students' abilities rather than laying out the consequences of not doing things. Students' are much more likely to get and stay motivated to do their work. This endorsement provides the reality frequency of teachers in both grade level 11 th and $12^{\text {th }}$. Teachers can play a pivotal role in providing and encouraging motivation in students. While Ministry of Education may keep students on task and motivated, allowing students - parents to have some choice and control over what happens at home is actually one of the best ways to keep them engaged. For example, allowing students-parents to choose the type of assignment they do or which problems to work on, can give them a sense of control that may just motivate them to do more.

In contrast, the lowest mean score of teacher perception of why students lack of motivation in grade 11,12 and 11 and12 belonged to Aspiration/ Future Utility subscale. These factors have a moderate effect on students' motivation since students at this age and stage of life tend not to put future's career as their utmost concern. The teachers most frequently attributed students' motivation to internal causes, specifically the students' view of the relevance and value of the topic and how it related to their future aspirations (Hardre and Sullivan, 2008). That was indicated, the teachers do not believe their students are not motivated to learn because they are just lazy and do not care about 
INTERNATIONAL JOURNAL OF ACADEMIC RESEARCH IN BUSINESS AND SOCIAL SCIENCES Vol. 8, No. 12, Dec, 2018, E-ISSN: 2222-6990 C 2018 HRMARS

learning period. Finally, the results showed disparity in teacher perceptions of importance and frequency, leading to the underutilization of the important of students lack of motivation issue.

Besides, prior studies that have noted the importance of teachers' neutral motivational perception level. Edwards and Smith, (2014) said that people pick neutral options because of ambivalence. People's responses in public opinion polls tend to gravitate towards neutral because they want to avoid the negative feelings associated with their conflicting feelings on an issue (Bishop, 1987). Additionally, picking a neutral option allows people to avoid the cognitive effort to choose between their positive and negative (Nowlis et al., 2008). Teachers' beliefs about motivational causes can predict how motivated their classroom environments were; teachers who believed that students' motivation was fixed at a certain level had less supportive classrooms than teachers who adopted the internally-focused beliefs described above (Hardré \& Sullivan, 2009).

Table 4: Descriptive Statistics of Teachers' Motivational Perception Factors

\begin{tabular}{|c|c|c|c|c|c|c|}
\hline \multicolumn{2}{|c|}{$\begin{array}{l}\text { Reasons of } \\
\text { Motivation } \\
\text { Class Level } \\
\end{array}$} & $\begin{array}{l}\text { Home } \\
\text { Factors }\end{array}$ & $\begin{array}{l}\text { Current } \\
\text { Relevan } \\
\text { ce Value }\end{array}$ & $\begin{array}{l}\text { Aspiration/ } \\
\text { Future } \\
\text { Utility } \\
\end{array}$ & $\begin{array}{l}\text { Peer } \\
\text { Factors }\end{array}$ & $\begin{array}{l}\text { Personal } \\
\text { factors }\end{array}$ \\
\hline \multirow[t]{3}{*}{11} & Mean & 3.1026 & 3.1128 & 2.9487 & 3.6615 & 3.5385 \\
\hline & $\mathrm{N}$ & 65 & 65 & 65 & 65 & 65 \\
\hline & $\begin{array}{l}\text { Std. } \\
\text { Deviation }\end{array}$ & .75674 & .75984 & .92277 & .83903 & 1.14669 \\
\hline \multirow[t]{3}{*}{12} & Mean & 3.2558 & 3.2481 & 3.1628 & 3.8837 & 3.3953 \\
\hline & $\mathrm{N}$ & 43 & 43 & 43 & 43 & 43 \\
\hline & $\begin{array}{l}\text { Std. } \\
\text { Deviation }\end{array}$ & .76924 & .64690 & .98500 & .56523 & 1.07215 \\
\hline $11 \&$ & Mean & 3.3333 & 3.4815 & 3.3704 & 3.9630 & 3.7778 \\
\hline \multirow[t]{2}{*}{12} & $\mathrm{~N}$ & 27 & 27 & 27 & 27 & 27 \\
\hline & $\begin{array}{l}\text { Std. } \\
\text { Deviation }\end{array}$ & .84226 & .81824 & 1.02671 & .86520 & 1.01274 \\
\hline \multirow[t]{3}{*}{ Total } & Mean & 3.1975 & 3.2296 & 3.1012 & 3.7926 & 3.5407 \\
\hline & $\mathbf{N}$ & 135 & 135 & 135 & 135 & 135 \\
\hline & $\begin{array}{l}\text { Std. } \\
\text { Deviation }\end{array}$ & .77833 & .74587 & .97078 & .77360 & 1.09792 \\
\hline
\end{tabular}

The table 4 shows that Peer Factor subscale had the highest mean score $(M=3.79, S D=0.773)$, followed by personal factors $(M=3.54, S D=1.098)$ and current relevance value $(M=3.22, S D=0.818)$. Likewise, the table indicate that teachers who taught both class level $11 \& 12$ had high perception ( $n=27, M=3.96, S D=0.865$ ).

Differences of Teachers' Motivational Perception based on Gender 
INTERNATIONAL JOURNAL OF ACADEMIC RESEARCH IN BUSINESS AND SOCIAL SCIENCES Vol. 8, No. 12, Dec, 2018, E-ISSN: 2222-6990 C 2018 HRMARS

To evaluate the differences of teacher motivational perception at Omani, Welayat Sumail, public school based on Genders (male and female) has used independent $t$ - test normal distribution.

Table 5: Comparison of Teachers' Motivational Perception Based on Genders

\begin{tabular}{llllll}
\hline Gender & $\mathbf{N}$ & Mean & Std. Deviation & $\mathbf{T}$ & p value \\
\hline Male & 71 & 3.229 & 0.322 & & \\
Female & 64 & 3.366 & 0.411 & 2.163 & 0.032 \\
\hline
\end{tabular}

The results of comparing the means of one sample t- test are illustrated in table 5 which shows that a significant $(t=2.163, p<0.05)$ differences between male $(M=3.22, S D=.322)$ and female $(M=3.36$, $S D=.411)$. The mean differences of female teachers' motivational perception were higher than male teachers at Sumail, Oman public school.

Teachers' Motivational Perception based on Grade Level ANOVA test was run to compare the means of teacher motivational perception among grade level. Table 6 results of ANOVA showed that there was a significant difference among grade level for teacher motivational perception $(F=3.928, p=.022)$.

Table 6: Descriptive Statistics of Teachers' Motivational Perception Based on Grade Levels

\begin{tabular}{llll}
\hline Grade Level & $\mathbf{N}$ & Mean & Std. Deviation \\
\hline $\mathbf{1 1}$ & 65 & 3.215 & 0.343 \\
$\mathbf{1 2}$ & 43 & 3.320 & 0.347 \\
$\mathbf{1 1 \& 1 2}$ & 27 & 3.444 & 0.434 \\
\hline
\end{tabular}

Table 6 used to compare all three classes and results of multiple comparisons. The table showed that only level $11^{\text {th }}$ had statistically different with level $11^{\text {th }} \& 12^{\text {th }}(M=0.229, p=.019)$.

Table 7: Results of Pos-Hoc Tests for Teacher Motivational Perception among Grade Levels

\begin{tabular}{lllll}
\hline (I) GRADE LEVEL & $\begin{array}{l}\text { (J) } \\
\text { LEVEL }\end{array}$ & $\begin{array}{l}\text { GRADE } \\
\text { Mean }\end{array}$ & $\begin{array}{l}\text { Difference (I- SE } \\
\text { J) }\end{array}$ & P value \\
\hline $\mathbf{1 1}$ & 12 & 0.104 & 0.072 & 0.314 \\
$\mathbf{1 1}$ & $11 \& 12$ & $0.229^{*}$ & 0.083 & 0.019 \\
$\mathbf{1 2}$ & $11 \& 12$ & 0.125 & 0.089 & 0.347 \\
\hline
\end{tabular}

*. The mean difference is significant at the 0.05 level

Teachers' Motivational Perception based on Teaching Experiences 
INTERNATIONAL JOURNAL OF ACADEMIC RESEARCH IN BUSINESS AND SOCIAL SCIENCES

Vol. 8, No. 12, Dec, 2018, E-ISSN: 2222-6990 C 2018 HRMARS

The table below used means and standard deviation to compare the means of teachers' motivational perception based on teaching experiences class level. Table 8 shows the level of teacher motivational perception among five categories of teaching experiences.

Table 8: Descriptive Differences Motivational Perception based on Teaching Experiences

\begin{tabular}{llll}
\hline Teaching Experiences & $\mathbf{N}$ & Mean & Std. Deviation \\
\hline & & & \\
From 10-15 Y & 29 & 3.360 & 0.406 \\
From 15-20 Y & 47 & 3.287 & 0.344 \\
From 5-10 Y & 35 & 3.250 & 0.386 \\
Less than 5 Y & 13 & 3.308 & 0.421 \\
More than 20 Y & 11 & 3.277 & 0.325 \\
\hline
\end{tabular}

Due to the unequal and small sample size in some groups, the results and the figure below showed that there was no significant difference among five categories of teaching experiences for teachers' motivational perception $\left(\chi^{2}=2.008, p>0.05\right)$.

Academic Achievements Level

The study measurement was based on the indicators of student academic. Academic achievements in eight public schools were calculated based on the means and average of all essentials subjects' students' studies. The means showed (class $11^{\text {th }} M=66.27$; class $12^{\text {th }} M=65.82$; class $11^{\text {th }} \& 12^{\text {th }} M=$ 67.06). The descriptive statistic shows the students academic achievement in grade 11 were $48 \%$ between medium and failed, $22 \%$ were good and $22.8 \%$ in high grades. Whereas, students in grade 12 were $51 \%$ between medium and failed, $29 \%$ were good and $20 \%$ in high grades.

Table 9: Descriptive Statistics of students' Academic Achievements Level

\begin{tabular}{|c|c|c|c|c|c|c|c|c|}
\hline & \multirow[t]{3}{*}{$\mathbf{N}$} & \multirow[t]{3}{*}{ Mean } & \multirow{3}{*}{$\begin{array}{l}\text { Std. } \\
\text { Deviation }\end{array}$} & \multirow{3}{*}{$\begin{array}{l}\text { Std. } \\
\text { Error }\end{array}$} & $95 \%$ & nfidence & \multirow[t]{3}{*}{ Minimum } & \multirow[t]{3}{*}{ Maximum } \\
\hline & & & & & \multicolumn{2}{|c|}{ Interval for Mean } & & \\
\hline & & & & & $\begin{array}{l}\text { Lower } \\
\text { Bound }\end{array}$ & $\begin{array}{l}\text { Upper } \\
\text { Bound }\end{array}$ & & \\
\hline 11 & 65 & 66.2782 & 6.37120 & .79025 & 64.6995 & 67.8569 & 53.65 & 74.08 \\
\hline 12 & 43 & 65.8287 & 8.81769 & 1.34468 & 63.1150 & 68.5424 & 53.65 & 75.98 \\
\hline $11 \& 12$ & 27 & 67.0639 & 5.84623 & 1.12511 & 64.7512 & 69.3766 & 57.94 & 73.93 \\
\hline Total & 135 & 66.2922 & 7.11181 & .61209 & 65.0816 & 67.5028 & 53.65 & 75.98 \\
\hline
\end{tabular}

The academic achievements in Sumail, Oman public school were calculated based on students' core subjects for grade level 11 and 12 . The academic achievements were calculated based on average of 
all subjects for each school. The descriptive statistic in table 9 shows that the students' academic achievements ranged between (Min=53.65) and (Max=75.98). The mean and standard deviation of students' academic achievements was $(M=66.29, S D=7.11)$ which indicates the students have moderate academic achievements.

Omani moderate academic achievement is one of the most important issue that hinder the work of the modern schools and prevent them from fulfilling their goals and mission in an appropriate way. Besides, Al-Zobi and Younis (2015) said that anyone who practices teaching admits that academic achievement exists in almost every classroom. In case there is a group of students who are unable to keep pace with the rest of their colleagues in achievement and comprehending the curriculum, and often this group is turned into a source of trouble and inconvenience, which may disrupt the educational process in the classroom or disorder within the school. The issue of academic achievement is a global problem that any community hardly can avoid, that twenty students of every hundred have weakness in the academic achievement by taking random samples from different communities (Jazmawi, 2008). The finding reveled that students' indicators results in Welayat Sumail are largely statistically important for school's academic performance level for future outcomes. The increased motivation observed in the older students supports that when faced with appearing less capable, older students will engage in behaviors designed to "save face" . Students who perceive themselves as less capable will engage in behaviors that will allow them to attribute their failures to external causes, and these behaviors may become akin to self-fulfilling prophecies. The older students also exhibited higher tendency to attribute failure to stable, internal and global causes.

Furthermore, when the lack of interest in studying is coupled with being absent and missing classes, the issue becomes worst for students' academic achievements. Not doing the required assignments at home, laziness, using mobile phones for playing games/texting, feeling sleepy in classroom because of staying late up at night, spending too much time with friends, not having an effective study schedule, dislike to come to school, having no plan for the future are among the main problems the students discussed in their essays. Finally, the indicator of Omani students' result is still unacceptable recently. All these factors provide an overview on the importance of dealing with scientific indicators of students outcomes and educational practices with teacher partnership while creating a participatory learning motivational environment between school, education authorities, and society especially in secondary schools.

\section{Conclusion}

The research indicates several important implications that could arguably be of scientific and practical educational importance. Firstly, this finding has important implications for developing deeper understanding on teachers' motivational perception and students' academic achievement. One of these important issues was the moderate teachers' perception of students lacking of motivation. Even though those causes or reasons of students lacking of motivation had been studied internationally; this study is new study based on causes factors in Oman public schools. Ministry of Education in Oman, school supervisors, principals, teachers, social workers and counselor should be focusing on these reasons that impacted school students motivation especially in grade 11th and 
12th. As the literature indicates that a higher degree of teacher perception and beliefs corresponds to better students outcomes, this finding suggests a potential deterioration of the current learning environment. School authorities, policy makers, administrators and teacher educators can use these findings as tools to support teachers in developing and accurately self-monitoring their motivating perceptions for Omani future learning outcomes. Focusing on achievement does not always improve motivation, but focusing on motivation does promote achievement. Supporting personal motivation to learn (not just get high grades or do well in tests) can bridge the gap for underachieving students and support future success (Hardre, 2012). This research has thrown up many questions in need for further investigation between motivation and academic achievement in Omani public schools to understand students' results indicators of core subjects in others stage of the study. Further work needs to be done to examine what teachers teach in their post-secondary courses and professional development about motivation. It would be interesting to assess the effects of teachers' preparation in motivation specifically to equips effectively to meet the students' needs that they encounter in real professional practice.

\section{References}

Abiola, A. B. Y. \& Oluwatoyin, F. C. (2015). Effect of Teachers' Motivational Strategies on Students' Academic Achievements: Experience from Nigeria. Malaysian Online Journal of Educational Management (MOJEM). April 2015, volume 3, issue 2, 70-81e-issn no: $2289-4489$.

Adeyemi, B. A. (2008), Effects of cooperative learning and problem-solving strategies on Junior Secondary School Students' Achievement in Social Studies Institute of education n, Faculty of Education. Obafemi Awolowo University. Nigeria. Postal Code: 220005 (C) Education \& Psychology $1+D+i$ and Editorial EOS (Spain), Electronic Journal of Research in Educational Psychology. ISSN. 1696-2095.No 16, Vol 6 (3) 2008, pp: 691-708.

Fan, F. (2012). Teacher: students' interpersonal relationships and students' academic achievements in social studies. Teachers and Teaching, 18(4), 483-490. http://dx.doi.org/10.1080/13540602.2012.696048

Fishbein, M., \& Ajzen, I. (2010). Predicting and changing behavior: The reasoned action approach. New York: Taylor \& Francis.

Ford, Valjeaner, B., \& Roby, Douglas. E (2011). "Why Do High School Students's Lack Motivation in the Classroom?" New Atlantic Weekly 1.3: 13-15. EBSCOhost. MasterFILE.

Gan, Z. (2004). Attitudes and strategies as predictors of self-directed language learning in an EFL context. International Journal of Applied Linguistics, 14(3), 389-411.

Gaskin, J. (2012). Gaskination's statwiki. Retrieved November 20, 2015, from http://statwiki.kolobkreations.com

Gavora, P. Slovak pre-service teacher self-efficacy: theoretical and research considerations. The New Educational Review. Vol. 21, No. 2 (2010), pp. 17-30.

Gawel, J. E. (1997). Herzberg's theory of motivation and Maslow's hierarchy of needs. Practical Assessment, Research \& Evaluation, 5(11), 3.

Ghazvini, S. D., \& Khajehpour, M. (2011). Gender differences in factors affecting the academic performance of high school students's. Procedia-Social and Behavioral Sciences, 15, 10401045. 
INTERNATIONAL JOURNAL OF ACADEMIC RESEARCH IN BUSINESS AND SOCIAL SCIENCES

Vol. 8, No. 12, Dec, 2018, E-ISSN: 2222-6990 @ 2018 HRMARS

Gbollie, Charles, and Harriett, Pearl Keamu. (2017). "Students' Academic Performance: The Role Of Motivation, Strategies, And Perceived Factors Hindering Liberian Junior And Senior High School Students's Learning." Education Research International: 1-11.

Gehlbach, H., Brinkworth, M., \& Harris, A. (2012). Changes in teacher-students' relationships. British Journal Of Educational Psychology, 82(4), 690-704. http://dx.doi.org/10.1111/j.20448279.2011.02058.

Glynn, S. M., \& Koballa, T. R. (2006). Motivation to learn in college science. Handbook of college science teaching, 25, V32.

Goetz, J. W., Cude, B. J., Nielsen, R. B., Chatterjee, S., \& Mimura, Y. (2011). College-based personal finance education: Students' interest in three delivery methods.

Gottfried, A.E., J.S. Fleming, and A.W. Gottfried. (2001). Continuity of academic intrinsic motivation from childhood through late adolescence: A longitudinal study. Journal of Educational Psychology 93, no. 1: 3-13.

Gravetter, F., \& Wallnau, L. (2012). Statistics for Behavioral Sciences ( th $^{\text {th }}$ ). Belmont, CA: Wadsworth Cengage Learning. Retrieved from: https://books.google.com/ books? id $=6 R I K A A A A Q B A J \&$ pgis

Guay, F., Ratelle, C. F., \& Chanal, J. (2008). Optimal learning in optimal contexts: The role of selfdetermination in education. Canadian Psychology/Psychologie Canadienne, 49(3), 233.

Guilloteaux, M. J., \& Dörnyei, Z. (2008). Motivating language learners: A classroom-oriented investigation of the effects of motivational strategies on students' motivation. TESOL quarterly, 55-77.

Han, J. \& Yin, H. (2016). Teacher motivation: Definition, research development and implications for teachers. Cogent Education,3(1).http://dx.doi.org/10.1080/2331186x.2016

Hardré, P.L., K.A. Davis, and D.W. Sullivan. (2008). Measuring teacher perceptions of the 'how' and 'why' of students' motivation. Educational Research and Evaluation 14, no. 2: 155-79.

Hardré, P.L., K.A. Davis, and D.W. Sullivan. (2009). Motivating adolescents: secondary school teachers perceptions and classroom practices, Teacher development13(1),1-16.http://dx.doi.org/, $10.1080 / 13664530902858469$

Hardre', P. L., \& Hennessey, M. N. (2013). What they think, what they know, what they do: Rural secondary teachers' motivational beliefs and strategies. Learning Environments Research, 16(3), 411-436. doi:10.1007/s10984-013-9131-0

Hardre', P. L. (2007). Preventing motivational dropout: A systemic analysis in four rural high schools. Leadership and Policy in Schools, 6, 231-265.

Hardre', P. L. (2008). Taking on the motivating challenge: Rural high school teachers' perceptions and practice. Teacher Education and Practice, 21, 72-88.

Hardre', P. L. (2010). Examining high school teacher characteristics and motivating strategies. Teacher Education and Practice, 23, 226-253.

Hardre', P. L., \& Burris, A. (2011). What contributes to TA development: Differential perceptions of, and responses to, key design features in training and development. Instructional Science, 40, 93-118. 
Hardre', P. L., \& Hennessey, M. (2010). Two rural worlds: Differences of rural high school students' motivational profiles in Indiana and Colorado. Journal of Research in Rural Education, 25(8), $1-32$.

Hicks, J. H., Kremer, M., Mbiti, I., \& Miguel, E. (2011). Vocational education voucher delivery and labor market returns A randomized evaluation among Kenyan youth. Report for Spanish Impact Evaluation Fund (SIEF) http://siteresources. world bank. org/INTHDOFFICE/Resources/VocEd_SIEF_Report_2011-04-07 final. pdf.

Holbrook, J. (2003). Increasing relevance of science education: The way forward. Science Education International, 14(1), 5-13.

Hulleman, C. S., \& Harackiewicz, J. M. (2009). Promoting interest and performance in high school science classes. Science, 326(5958), 1410-1412.

Jonassen, D. H. (2011). Learning to solve problems: A handbook for designing problem-solving learning environments. New York: Routledge.

Jalbani, L. N. (2014), The Impact of Effective Teaching Strategies on the Students' Academic Performance and Learning Outcome, Munich, GRIN Verlag, http://www.grin.com/en/ebook/300046/the-impact-of-effective-teaching-strategies-on-the-students's-academicperformance 